\title{
Nyai Dadah : The Elasticity of Gender Roles and Life History of Pesantren Woman Leader
}

\author{
Siti Chusniyah ${ }^{\bowtie}$ Moh Yasir Alimi \\ Sociology and Anthropology Major, Social Science Faculty, Semarang State University, Indonesia
}

Permalink/DOI: http://dx.doi.org/10.15294/komunitas.v7i1.3602

Received : January 2015; Accepted: February 2015; Published: March 2015

\begin{abstract}
This article discusses the life of Nyai Dadah, a woman leader of a pesantren (Islamic boarding school) in Central Java, Indonesia, through life history method, to shed light upon the gender elasticity in the pesantren and her struggle to promote girl education in Indonesia. Nyai Dadah is the eldest daughter of Kiai Zubaidi, the founder of pesantren 'Al Asror'. After her father had passed away, she continued the struggle of her father managing the pesantren. His younger brother was still in religious training, and when he completed the study she passed the leadership to him and then created a pesantren for girls. The study revealed that the pesantren had strategies to promote girl education and did not close itself from the rise of women's leadership. Nyai Dadah with her capabilities was able to manage the pesantren for girls. Nyai Dadah played the roles either as a 'Nyai' in the pesantren or a housewife, and religious leader in her village.
\end{abstract}

\begin{abstract}
Abstrak
Menggunakan metode life history, penelitian ini bertujuan untuk mengungkapkan secara detil ketokohan seorang figur perempuan atau pemimpin pesantren di Semarang, yang disebut sebagai nyai. Life history nyai digunakan untuk menyampaikan perjuangan dan peran beliau di pesantren dan masyarakat. Nyai yang dikaji dalam penelitian ini adalah Nyai Dadah, anak perempuan tertua dari Kiai Zubaidi, pendiri Pesantren Al Asror, yang sekarang menjadi nyai di Pesantren Putri Huffadhul Quran Al Asror sejak tahun 2002 hingga sekarang. Studi ini berdasarkan pada konsep life history dan teori negosiasi gender. Penelitian menunjukkan bahwa pesantren tidak selalu menutup dirinya terhadap munculnya kepemimpinan perempuan. Nyai Dadah dengan kemampuannya, mampu mendirikan dan mengelola pesantren putri. Nyai Dadah menjalankan perannya baik sebagai seorang nyai di pesantren atau seorang ibu rumah tangga. Nyai Dadah juga berkontribusi di dalam masyarakat dengan menjadi penasehat Fatayat NU cabang Patemon dan memprakarsai ngaji selapanan sejak sepuluh tahun yang lalu sampai sekarang.
\end{abstract}

Keywords: life history; nyai; woman leader; pesantren

How to Cite: Chusniyah, S. \& Alimi, M. Y. 2015. Nyai Dadah : The Elasticity of Gender Roles and Life History of Pesantren Woman Leader. Jurnal Komunitas, 7 (1): 112-117 doi: 10.15294/komunitas.v7i1.3602

(c) 2015 Semarang State University. All rights reserved 


\section{INTRODUCTION}

Pesantren (Islamic boarding school) is one institution that historically has been around in Indonesia. The education of pesantren becomes the choice for the people of Indonesia because most of them are Muslim. Pesantren is regarded as education that emphasizes on character and morality education. The development of pesantren in Indonesia until now has brought up modern pesantren with more various education styles. However, although a large number of pesantren have emerged, there are still some traditional pesantren in several areas in Indonesia.

A pesantren is socio-historically seen as the oldest Islamic educational institution in Indonesia that was established by the Islamic scholars. Pesantren is established in order to educate people to understand and implement the teachings of Islam, which emphasizes the importance of religious morality as a life guide. The oldest, in this sense, means that pesantren is an institution that has long lived since hundreds of years ago, has even become the deepest part of the life system of most of the Muslims in Indonesia and varied the dynamics of Indonesia (Faiqoh, 2003: 139).

The term pesantren according to Wahid (in Faiqoh, 2003: 143) is an educational institution of Islamic religio-traditional that has historical roots not only in Indonesia but also in Southeast Asia although the terminology varies, in Aceh for example, pesantren is commonly referred to as rangkang or dayah, in Java and Madura is termed pondok pesantren, whereas in Malaysia, the Southern Philippines and Southern $\mathrm{Mu}-$ angthai is commonly referred to pondok. In line with the opinion of Wahid, Dhofier (in 2013: Arifin, 25) says that in the Indonesian culture, there are various terms used to describe the traditional Islamic system of education or pesantren. In Java, it is usually referred to as pesantren, pondok or pondok pesantren.

Pesantren has sections that have become a trademark. Pesantren is usually set in a vast environment that consists of a house/s of Kiai or Nyai (the elders), a mosque/s, and a boarding school building/s. Dhofier (in
Arifin 2013: 28) states “... some basic elements that must be available in any pesantren are pondok (dormitory), mosque, kitab kuning teaching, santris and the Kiai".

In pesantren, Kiai has charisma as a leader because of the knowledge and the religion science. Nyai (the wife of the Kiai) who also leads the girl pesantren is a social figure that has very strong faith as a Muslim and is also respected. However, there is still a presumption in the wider community that the success of the Nyai in leading pesantren is due to the influence and role of the Kiai as her husband, so that the existence of Nyai as a leader of the pesantren is because of her husband, not because of her ability. So, women cannot exist because of its ability but still linked by something else which in this case is her husband who is the Kiai in the pesantren (Faiqoh, 2003: 34).

Talking about girl pesantren does not escape from the studies that have been done by Faiqoh (2003) and Srimulyani (2012). Both give a history of the first daughter of a pesantren founded in the era of the 9o's. Faiqoh (2003) studied in girl pesantren in the area of Kajen and Pati, Central Java while Srimulyani (2012) was doing a fieldwork in East Java, specifically in Kwaron, Diwek.

In a review of history, the embryo of a girl pesantren was pioneered by Nyai Nafisah Sahal Mahfudh who established pesantren 'Al Badi'iyah' (Faiqoh, 2003: 177). In her study about Nyai as a figure who is able to make changes in the world of pesantren, Faiqoh (2003) explains that after Nyai Nafisah had established 'Al Badi'iyah', many girl pesantrens appeared. Based on the data of the number of the pesantren in Kajen and Pati presented by Faiqoh (2003), there are 27 pesantrens and are rendered with eight special pesantren for girls, i.e. Pesantren 'Masyitoh', Pesantren 'Manbatul Ulum' for girls, Pesantren 'Roudhotul Ulum' for girls, Majlis Ta'lim 'Al Hikmah', Pesantren Manbaul Huda for girls, Dormitory 'Kauman' for girls and Pesantren 'Salafiyah' for girls. Of the twenty-seven pesantrens, only two pesantrens revealed to be taken care by the Nyai, whereas in fact there are other Nyais that are not referred to as the Nyai. Their husbands 
are stated as the leader of the girl pesantrens instead.

In Central Java, the first pesantren for girls was established by Nyai Nafisah while in East Java it was pioneered by Nyai Nurkhodijah. Srimulyani (2012: 74) reveals that the first pesantren for girls in Jombang is Pesantren 'Denanyar', and it is also the first pesantren for girls in the community of NU. Initially, in 1917, Kiai Bisri Syansury only prepared a pesantren only for male students. In 1919, due to the efforts of Nyai Khodijah in inviting local women, the pesantren began to incur some neighbor girls who came to the pesantren and studied formally at the rear terrace of the residence of Kiai Bisri.

A lot of pesantrens in Indonesia were founded by a Kiai. Pesantren 'Tebuireng' in Jombang, East Java was established by Kiai Hasyim Asy'ari, Pesantren 'Lirboyo', Jawa Timur was founded by Kiai Abdul Karim, Pesantren 'Al Falah', Ploso, Kediri, was founded by Kiai Khamim Jazuli, Pesantren 'Darul Lughoh Wa Da'wah' in Bangil, Madura was founded by Habib Hasan Baharun. In Central Java, there are several prominent pesantrens such as Pesantren 'Al-Anwar', Sarang, founded by Kiai Maimun Zubair, Pesantren 'Roudhotut Tolibin' in Rembang is now taken care by Gus Mus, originally founded by Kiai Bisri Mustofa, father of Gus Mus, $P e-$ santren 'Darus Salam', Jatibarang, Brebes, founded by Kiai Sholeh Basalamah. Many pesantrens in Java and outside Java Island were founded by a Kiai.

In Gunung Pati, one of the sub districts in Semarang, specifically at the campus of the State University of Semarang, there are also a number of pesantrens, Pesantren 'Aswaja' founded by Kiai Masrohan, Pesantren 'Al Salafi Asror' founded by Kiai Zubaidi, and the others like 'Al Uswah' and 'SGJB' (Sunan Gunung Jati Ba'alawi) are taken care by a Kiai. The researchers found a pesantren for girls located in the area of State University of Semarang run and founded by a Nyai, Pondok Pesantren for girls 'Huffadhul Quran Al Asror' (PP. HQ. Al Asror). This is where the researchers felt interested in doing an ethnographic study of life history to know the phenomenon of pesantren founded by a Nyai, an uncommon phenomenon according to the researchers.

The interest of the researchers is in conjunction with what is expressed by Srimulyani (2012) which examines the three influential Nyais in Jombang, East Java. Many works have done to investigate pesantren and other traditional Islamic educational institutions in Indonesia. Such works have tested pesantren tradition, leadership, transmission and intellectual of their organization with Nahdlatul Ulama and other related topics. After reading many of these studies and the study of the Qur'an which was published, I feel that it looks reasonable to conclude that women have got less attention. In all studies of pesantren, Kiai often becomes the main subject. Until 2002, the time where Srimulyani did a fieldwork on women and pesantren produced a bit of good scientific studies whether in English or in Bahasa that specifically deal with the topic of women and pesantren particularly toward the leadership and the representation of the girl pesantren.

\section{METHODS}

This paper is based on an ethnographic research I did in Pondok Pesantren for girls 'Huffadhul Quran Al Asror' during January to March 2015. I used the life history method to obtain a picture of how gender roles are negotiable by a Nyai in a pesantren. In this ethnographic research, I really took advantage of voice recorder, one of the features in a cell phone to record all the ethnographic interviews that I did. In addition, I also wrote field notes to facilitate the composition of the research report.

\section{RESULT AND DISCUSSION}

Life history is a long and detailed note on the life history of the subject. Life history views all journey of life are precious and have a meaning (Salim, 2009). Individual can learn something valuable from the his/her own self experience in the past as well as from other people's experience of life especially if the experience is highly specialized and not necessarily owned in everyone's life journey. Through the record of this life history, eth- 
nographic researchers will understand in detail what the life of the research subject is and the factors which affect it including the culture in the environment.

Arif (2012) says that the record of life history requires the ability of the researchers to be sharp in seeing every detail of a person's life. Therefore, it will be clearly illustrated how the way of life of the subject from birth until adulthood and the important events that became the turning point in the life history of the subject can be found. Even though it is almost the same as the pattern of autobiography, but there is a difference especially on the stronger effort in writing to avoid the subjectivity of the author.

The use of the concept of life history in the study notices four elements in many definitions from the anthropological approach about life history. As stated by Shaw (in Danahay, 200o), there are four suggested elements in many definitions of anthropological approach towards life history: (1) life history emphasizes the importance of socio-cultural setting of the storyteller; (2) life history focuses on the perspective of the individual, the specific individual; (3) a long time, so that the history of someone looks and is associated with various things toward the group or regional local history; (4) life history is related to local history from the viewpoint of indigenous storyteller.

My research took place in Semarang, at Pondok Pesantren for girls 'Huffadhul Quran Al Asror' located on 1 Kauman Street Patemon. Pondok Pesantren for girls 'Huffadhul Quran $\mathrm{Al}$ Asror' is one part of 'Al Asror' Foundation, an institution which provides Islamic education. The name is often abbreviated as P.P. 'H.Q. Al Asror' or 'H.Q $\mathrm{Al}$ Asror'. Seen from the naming of the pesantren, 'huffadhul quran' means people who memorize, so it can be said that this pesantren scores people who can memorize the Quran. However, in this pesantren, there are not only santris (students) who can memorize the Quran, but also some who do not memorize the Quran. The majority of the santris are students of the State University of Semarang. Currently, there are 61 santris consisting of 46 students UNNES, 6 alum- ni of UNNES and 9 students of MTs (Junior High School) and MA (Senior High School) 'Al Asror'.

\section{Life History of Nyai Dadah}

P.P. H.Q. Al Asror is taken care by a Nyai named Nyai Mahmudah Masruroh Al Hafidhoh. The last two words of the name is a title she has received because she is a hafidhoh of the Quran, a person who can memorize the Quran. Although it can be said that P.P. H.Q. Al Asror is a pesantren who is less known because its status is still under the auspices of $\mathrm{Al}$ Asror Foundation, this pesantren has contributed in educating its santris to have Islamic personality in accordance with the Quran. Most of the santris who are students are greatly helped in terms of learning the Quran. A few students confessed, living at P.P. H.Q. Al Asror is the first time for them to live their lives in a boarding school with the routine such as having prayers in congregation, doing Dhikr together, reciting the Quran, studying Kitab Kuning, and the other boarding school routine in general.

Bu Nyai Mahmudah Masruroh is a Nyai and a housewife. 'Ibu' (Ma'am), the familiar way to call Bu Nyai by her santris is a descendant of the Kiai and elders of Patemon village. Among the public, Bu Nyai is called Bu Dadah. She is the first daughter of a couple, Kiai Zubaidi and Mbah Siti Markonah. In fact, she is not the first child because Kiai Zubaidi had a son named Muhammad Imam Jauhari Mustofa. However, his age was not long, seventeen days after his birth, he passed away. Three years later, it was the birth of a daughter who was later given the name of Masruroh Mahmudah.

Bu Nyai was born 45 years ago, precisely in 1970, in a modest family. His mother was a housewife who was also working on a rice field. While his father, Kiai Zubaidi was a remarkable figure of the elders in Patemon Village. Kiai Zubaidi is a very simple figure in his life; he lives and fills his life with religious services and always does Dhikr. His simplicity and the piety of his religious services have made his twelve children currently live in a well-established life and they have a very good education history, both pe- 
santren education and formal education.

In 1976, after Bu Nyai had finished her study in an elementary school, she did mondok (lived in a boarding school) in Betengan, Demak, to memorize Juz Amma (the 3oth section of the Quran) with Nyai Fatimah. One year later, Bu Nyai moved to Pesantren 'Al Badriyah' while continuing her middle school education in Futuhiyah, Mranggen, Demak. That was where Bu Nyai started memorizing the Quran until in 1984 she completed his memorization of the Holy Quran. The experience of mondok formed the character of Bu Nyai to become a leader because Kiai Zubaidi expected that she could later practice her knowledge by establishing a pesantren.

\section{Nyai Leadership}

About the leadership of women in Islam, in fact it is already clear that Islam never forbids women to be a leader in the community. Arnez (2009), says ".... there is no verse in the Quran indicating that women are not allowed to become leaders in society, as men and women are equal". Arnez (2009) in his writing entitled 'Empowering Women Through Islam: Fatayat NU Between Tradition and Change', declares that Fatayat $\mathrm{Nu}$ as an advanced group argues that banning a woman from becoming a president is contrary to the Islamic sources. According to them, the women deserve the right to occupy leadership position as long as they are capable and meet the required conditions, such as competence, confidence, and leadership skills. If in a community, a woman has more competence than other members of the community, she can choose to become community leader.

Srimulyani (2012) who has made observations on the lives of girls in a pesantren, their representation, and their leadership, especially Nyai as the important figure in the pesantren, sees that woman's leadership in a pesantren is a result of the negotiation. The shape of the negotiation is to remain instrumental in the pesantren, although structurally, she is often not counted as a leader of a pesantren.

Srimulyani (2012) observed the lives of the girls in a pesantren, their representation, and their leadership, especially Nyai as the important figure in the pesantren. An observation on her life and her representation has described something beyond the limitations of gender bias when more complexity from gender roles can be understood. It cannot be denied, even though a pesantren is associated with religious patriarchal values that emphasize the field division of public and personal, the lives of some Nyais do illustrate how the division of the field can be negotiated (Srimulyani, 2012: 136).

Woman's leadership in a pesantren is usually not visible and examined by the researchers before, because if you talk about the leadership of a pesantren, which always appears as a prominent leader is the Kiai. Although in reality, the women in the family of the Kiai such as wife, daughter, sister, have a large role in the management of a pesantren, especially pesantren for girls. Srimulyani (2012: 45) says, in fact, the leadership of a pesantren will always end up in the hands of a close family of the Kiai, whether it is consanguineal or affinal. The leadership period is unlimited; usually a substitute will remain in this position until his death. In the official archive, the name of the Kiai always appears as a leader, though in daily fact, especially in a pesantren for girls, his wife, his children, his mother, or even his sister will have a prominent role. In 2003, when I visited Pesantren 'Al Fatimid', the biggest sub pesantren of Pesantren 'Tambak Beras' that is famous in Jombang, its leader was Kiai Natsir Abd Fattah, although his wife was also actively involved in teaching and leadership. His mother, Nyai Musyarofah, is Nyai sepuh (senior Nyai) and asked for opinions in matters relating to the pesantren, her position was similar to the Board of Advisors of the pesantren.

At that time, Nyai Musyarofah still led the congregation prayer of santris from the girl pesantren in a small mosque that merged with the pesantren building. In Pesantren 'Lirboyo', two daughters of Kiai Anwar were active in organizing two pesantrens for girls. In a traditional pesantren in Pacul Gowang, Kiai Aziz Mansur was assisted by his wife and his sister, Nyai Farida, who had 
more knowledge in the study of the Quran and had memorized the entire Quran.

The role of Bu Nyai in the pesatren is to educate the santris to be capable of reciting the Quran well even memorizing it. $\mathrm{Bu}$ Nyai also becomes the figure of mother for the santris. Bu Nyai in her everyday life in the pesantren acts like a mother for her children. For example, Bu Nyai becomes a place for sharing and telling their problems. Everytime the santris want to come out from the pesantren, they bid farewell first to $\mathrm{Bu}$ Nyai. Other role performed by Bu Nyai is being a manager in the pesantren. Bu Nyai manages the finance, including managing the budget of the pesantren for the payment of daily needs and electricity of the santris.

As a Nyai in the community, Bu Nyai does not only have roles in the pesantren but also social responsibilities in the community. Bu Nyai has a strategic role within the organization of Fatayat NU Patemon branch, i.e. as an advisor. Bu Nyai also manages the routine study for communities around Patemon, namely ngaji selapanan, held because seeing the condition in the vicinity where the mothers, especially the khafidhoh, have not yet had a container as a means to learn about the Quran and its tafsir (exclamation of passages of the Quran by supplying additional information).

\section{Gender Elasticity}

$\mathrm{Bu}$ Nyai is a figure who has a central role in the pesantren. Even though the central role that Bu Nyai carries out will ultimately be back in domestic affairs, Bu Nyai as the leader in the pesantren demonstrates that gender roles are a result of the construction of the community. Gender roles are elastic and can be negotiated. Although the roles are normative, individuals have the flexibility to perform their roles to face the reality and problems that occur in the community.

\section{CONCLUSION}

The existing review of pesantren which only focuses on the figure of the Kiai has made it identical with the patriarchal culture. In fact, at this moment, pesantren is an Islamic institution which does not close itself against the birth of dozens of women leaders in the pesantren. Nyai Dadah, a woman who takes care of Pesantren for girls 'Huffadhul Quran Al Asror' is a figure of Nyai that is capable of negotiating with pesantren patriarchal condition. Her leadership in the pesantren is evidence that gender roles in pesantren are negotiable. Bu Nyai can be an inspiration for students and the community in the surroundings to be the women who are able to actualize themselves and contribute to the social environment in the community.

\section{REFERENCES}

Arif, M.C. 2012. Etnografi Virtual: Sebuah Tawaran Metodologi Kajian Media Berbasis Virtual. Jurnal Ilmu Komunikasi. 2 (2): 165-179.

Arifin, A.Z. 2013. Charisma and Rationalisation in a Modernising Pesantren: Changing Values in Traditional Islamic Education in Java. Ph.D Thesis. Australia: Religion and Society Research Centre, University of Western Sydney.

Arnez, M. 2010. Empowering Women Through Islam: Fatayat NU Between Tradition and Change . Journal of Islamic Studies. 21 (1): 59-88.

Danahay, R.D. 20oo. Autobiography, Intimacy, and Ethnography. Dalam Atkinson, dkk. (Ed), Handbook of Ethnography. London, Thousand Oaks, New Delhi : Sage Publications.

Faiqoh. 2003. Nyai Agen Perubahan di Pesantren. Jakarta : Kucica.

Kholifah, S. 2014. Gendered Continuity and Change in Javanese Pesantren. Doctor of Philosophy Thesis, College of Arts, Victoria University.

Marzuki. 2014. Kepemimpinan Perempuan dalam Perspektif Ulama Pesantren di Aceh. Akademika. 19 (1): 167-183.

Raihani. 2001. Curriculum Construction In The Indonesian Pesantren: A Comparative Case Study Of Curriculum Development In Two Pesantren In South Kalimantan. Masters Research Thesis. Learning and Educational Development (LED), The University of Melbourne.

Salim, C., Mustika, T. \& Wahyuningsih, S. 2009. Kristalisasi Persepsi Terhadap Pribumi pada Perempuan Tradisional Tionghoa: Sebuah Life History. Anima, Indonesian Psychological Journal. 24 (2): 142-161.

Srimulyani, E. 2012. Women From Traditional Islamic Education Instituitons In Indonesia (Negotiating Public Spaces). Belanda: Amsterdam University Press. 